\title{
REguŁA HARMONIZOWANIA KONTEKSTÓW I PRESUPOZYCJE AKSJOLOGICZNE W PROCESIE WYKEADNI PRZEPISÓW PRAWA OCHRONY ŚRODOWISKA
}

Harmonizacja polskiego prawa ochrony środowiska z unijnym environmental acquis zmieniła niewątpliwie praktykę prowadzenia wykładni tych przepisów, nakierowując ją na efektywność. Podejście takie znajduje uzasadnienie $\mathrm{w}$ obowiązku dokonywania wykładni prawa krajowego zgodnie z dyrektywami. Z relewantnego orzecznictwa wynika, że wykładnia taka ma być czyniona „w świetle treści i celu dyrektywy”, bez względu na datę ustanowienia danych przepisów ${ }^{1}$. Jak wskazuje się przy tym, w prawie unijnym interpretacja celowościowa spełniać ma trzy funkcje: promować cel, zapobiegać niepożądanym rezultatom oraz wypełniać luki². U podstaw takiego kierunku myślenia leży teza, że „prawo które nie spełnia chociażby «minimalnych» warunków efektywności (jakkolwiek by formalnie obowiązywało) faktycznie przestaje istnieć" ${ }^{\prime 3},{ }^{4}$. Kryterium to kształtuje w konsekwencji zdolność i możliwość implementacji prawa unijnego, szczególnie jeśli postrzegać ją jako

* Mgr, radca prawny; e-mail: radcy@kpcic.gdynia.pl.

1 Szerzej zob. np. A. Wróbel, Sadowa wykładnia prawa państwa członkowskiego UE zgodnie z dyrektywami WE/UE, s. 4-7, http://www2.wpia.uw.edu.pl/files/podyplomowe/gospodarka_rynkowa/wrobel_andrzej.pdf [dostęp: 20.01.2018 r.] i powoływane tam wyroki ETS w sprawach: C-106/89 Marleasing; 14/83 von Colson; C-397/01 do C-403/01 Pfeiffer.

2 Zob. T.T. Koncewicz, Jak interpretować prawo europejskie, „Palestra” 2014, nr 5/6, s. 218.

3 J. Stelmach, Efektywne prawo, http://www2.wpia.uw.edu.pl/files/doktoranckie/ STELMACH\%20J.\%20-\%20EFEKTYWNE\%20PRAWO.doc?short= [dostęp: 20.01.2018 r.].

4 „Prawo w sumie jest takie, jakie wyłania się z ustalonej praktyki jego stosowania, a więc właśnie wrażliwość, kreatywność i wyobraźnia ludzi, którzy je stosują ma zasadnicze znaczenie dla udzielenia odpowiedzi, co jest normą obowiązującą [...]", M. Safjan, Prawa Polska (Seria „Szklane domy”), Warszawa 2005, s. 134. 
pożądany rezultat wykładni operatywnej, będącej elementem procesu decyzyjnego ${ }^{5}$.

Jednocześnie podnosi się jednak, obok aspektu ukierunkowania rozumienia przepisów „środowiskowych" na cel regulacji, że interpretacja tychże (od Traktatów unijnych począwszy, a na aktach wykonawczych kończąc) wymaga wzięcia pod uwagę - łącznie - ich ducha, systematyki i brzmienia. Na podkreślenie zasługuje kolejność, na której zbudowane jest powyższe wyliczenie ${ }^{6}$.

Na takim tle pojawia się szczególnie pytanie: co oznacza interpretacja przepisów „w duchu prawa ochrony środowiska”? Rozumienie i potrzebę takiej wykładni zobrazować mogą przede wszystkim antynomie ${ }^{7}$, do jakich może prowadzić poprzestanie tylko na wykładni językowej w określonych stanach faktycznych.

Dla zobrazowania problemu warto przytoczyć kilka przykładów z praktyki:

1) przez „odpady”, zgodnie z art. 3 ust. 1 pkt 6 ustawy o odpadach, rozumie się każdą substancję lub przedmiot, których posiadacz pozbywa się, zamierza się pozbyć lub do których pozbycia się jest obowiązany. Magazynowanie lub składowanie odpadów powinno się odbywać w miejscu na ten cel wyznaczonym, pod rygorem sankcji finansowych i karnych. Jak wypowiedział się Naczelny Sąd Administracyjny oceniając stosowanie ww. przepisów: „Kabel energetyczny linii podziemnej, który przestał być wykorzystywany do przesyłu energii elektrycznej i w związku z tym stał się bezużyteczny jest odpadem, którego posiadacz pozbył się w rozumieniu art. 3 ust. 1 ustawy o odpadach, niezależnie od tego czy jest on składowany bądź magazynowany w rozumieniu przepisów tejże ustawy. To zaś oznacza, że jego posiadacz winien odpad ten usunacćc ${ }^{\prime \prime}$. Symptomatyczne dla takiego statusu kabla może być jego usunięcie ze stanu majątkowego przedsiębiorstwa (likwidacja środka trwałego w księgach przedsiębiorcy).

5 Zob. L. Leszczyński, Wykładnia operatywna (podstawowe właściwości), „Państwo i Prawo" 2009, z. 6, s. 11-23 (szczególnie rozdz. II i III).

6 Zob. Z. Brodecki, T.T. Koncewicz, „Wspólnotowa rozumność” w Trybunale Sprawiedliwości Wspólnot Europejskich, [w:] M. Wyrzykowski (red.), Rozumność rozumowań prawniczych. Materiały z konferencji Zakładu Praw Człowieka Wydziału Prawa i Administracji Uniwersytetu Warszawskiego, która odbyła się 23 stycznia 2008 roku, Warszawa 2008, s. 162.

7 W znaczeniu: sprzeczność między dwoma wykluczającymi się twierdzeniami, z których każde wydaje się prawdziwe i uzasadnione, https://sjp.pwn.pl [dostęp: 20.01.2018 r.].

8 Wyrok NSA w Warszawie z dnia 19 grudnia 2008 r., II OSK 1688/07. 
Czy jednak prosta dyspozycja „usunąć” pozostanie jednoznaczna i oczywista, jeśli kabel ten przebiega przez wpisany do rejestru zabytków układ urbanistyczny historycznego miasta? Czy liczba ingerencji w zabytkową substancję miasta, narażających jej trwałość i ochronę, ma z tego (formalnego tylko) powodu, racjonalne uzasadnienie? Analogicznie, czy powinno się wydobyć likwidowany, odłączany od sieci i wyłączany z eksploatacji odcinek podziemnego rurociagu przesyłowego, jeżeli w okresie jego istnienia na powierzchni ziemi utworzono rezerwat przyrody, a wydobycie naruszałoby zakazy dotyczące tego rezerwatu? Stosowanie przepisów o gospodarowaniu odpadami w obu przypadkach nakazywane prawem, a w związku z tym in abstracto legalne - in concreto godzi w dobra chronione na podstawie innych przepisów, niszcząc je lub degradując w stopniu, który, jeśliby pozbawić takie działanie cech legalności, wypełniałby znamiona przestępstwa lub wykroczenia określonego przepisami ochrony przyrody czy o ochronie zabytków i opiece nad zabytkami ${ }^{9}$.

2) historyczna twierdza, unikat w skali kraju i zabytek wyjątkowej klasy, wymagający pilnie prac konserwatorskich ${ }^{10}$. Jednocześnie obiekt ten, ze względu na usytuowane w nim zimowisko nietoperzy, został objęty ochroną w postaci włączenia do sieci obszarów Natura 2000. Prace konserwatorskie, skutkujące usunięciem spękań i szczelin w murach oraz zmianą warunków klimatycznych obiektu, a także planowane prace restauratorskie, spowodują niedozwolone, negatywne i znaczące oddziaływanie na gatunki, dla których ochrony został wyznaczony obszar Natura 2000 - zmiany nastąpią w stopniu, w którym ich skutki nie poddają się kompensacji ${ }^{11}$. Wyjątki nie znajdują tu zastosowania, a zatem działanie takie powinno się więc spotkać z nakazem natychmiastowego wstrzymania

9 Zob. art. 187 ustawy z dnia 6 czerwca 1997 r. - Kodeks karny, Dz. U. z 2018 r. poz. 1600, tekst jednolity; art. 127 ustawy z dnia 16 kwietnia 2004 r. o ochronie przyrody, Dz. U. z 2018 r. poz. 1614, tekst jednolity; art. 110 ustawy z dnia 23 lipca 2003 r. o ochronie zabytków i opiece nad zabytkami, Dz. U. z 2017 r. poz. 2187, tekst jednolity.

10 Działania mające na celu zabezpieczenie i utrwalenie substancji zabytku, zahamowanie procesów jego destrukcji oraz dokumentowanie tych działań.

11 Art. 33 ust. 1 ustawy o ochronie przyrody: „Zabrania się, z zastrzeżeniem art. 34, podejmowania działań mogących, osobno lub w połączeniu z innymi działaniami, znacząco negatywnie oddziaływać na cele ochrony obszaru Natura 2000, w tym w szczególności: 1) pogorszyć stan siedlisk przyrodniczych lub siedlisk gatunków roślin i zwierząt, dla których ochrony wyznaczono obszar Natura 2000 lub 2) wpłynąć negatywnie na gatunki, dla których ochrony został wyznaczony obszar Natura 2000 lub 3) pogorszyć integralność obszaru Natura 2000 lub jego powiązania z innymi obszarami". 
lub podjęcia niezbędnych działań zapobiegawczych lub działań naprawczych $^{12}$. Niepodjęcie takich działań przyoblecze się co najmniej w zarzut braku należytego zabezpieczenia zabytku przed uszkodzeniem lub zniszczeniem - jeśli nie jego niszczenia w zamiarze ewentualnym. Dostrzec trzeba, że mówimy tu o swoistej konkurencji równoprawnych i równoważnych interesów publicznych powiązanych z narodowym dziedzictwem. Tylko umiejętna wykładnia operatywna aspiruje do roli „miecza”, jaki może przeciąć taki „węzeł gordyjski”.

3) miejscowy plan zagospodarowania przestrzennego, w związku z położeniem obszaru objętego planem w granicach parku krajobrazowego, ustanawia zakaz „realizacji inwestycji przemysłowych” oraz zakaz realizacji „rozległych terenów eksploatacji surowców”. Czy wydobycie osadów piasku i żwiru z koryta rzeki przez przedsiębiorcę sektora prywatnego (które wymaga pozwolenia wodnoprawnego i - w świetle orzecznictwa - koncesji na wydobywanie kopaliny ${ }^{13}$ ), przyjmujące rozmiar analogiczny do działań wymaganych dla utrzymania tych wód prowadzonych przez administratora wody, wyznaczony przez tego administratora, które nie rodzi skutków krajobrazowych innych niż związane z tym utrzymaniem wód (transport lądowy wydobytych osadów prowadzony poza obszarem parku) - należy zakwalifikować jako niezgodne z planem i niedozwolone ${ }^{14} \mathrm{Czy} w$ istocie tylko dlatego, że działania te prowadzi kto inny niż administrator wody, mają one odmienny status prawny? - mimo, że prace te realizują ten sam interes publiczny ( $\mathrm{z}$ tą różnica, że przedsiębiorca nabywa prawo do pożytków)? Czy kryteria podmiotowe powinny mieć wpływ na wynik wykładni i różnicować go w takim stopniu?

Oczywiście, skomplikowanie i specyfika podanych stanów faktycznych powoduja, że rekonstrukcja podstawy prawnej decyzji w poszczególnych sprawach jest trudna - nie poddaje się prostej ocenie, jak i nie daje w każdym przypadku takiego samego wyniku. Wypływa z nich natomiast jednoznaczna konkluzja o niewystarczalności samej litery prawa do podjęcia takiej decyzji.

12 Zob. art. 37 ustawy o ochronie przyrody.

13 Wyrok NSA z dnia 15 kwietnia 2011 r., II GSK 487/10: „[...] w przypadku szczególnego sposobu korzystania z wód polegającego na gospodarczym, zorganizowanym i ciągłym wydobywaniu kopaliny w postaci żwiru i piasku, działalność taka wymaga uzyskania koncesji jak i pozwolenia wodnoprawnego".

14 Pozwolenia wodnoprawnego odmawia się m.in. jeśli zamierzone korzystanie z wód jest niezgodne $\mathrm{z}$ ustaleniami miejscowego planu zagospodarowania przestrzennego. 
W sytuacjach jak powyższe, znalezienie rozwiązania zgodnego z prawem (tu: prawem ochrony środowiska), oddającego to prawo, wydaje się zależeć przede wszystkim od systemowego kontekstu przepisów budzących wątpliwość, jak i refleksji na temat wartości, jakie prawo w danym przypadku ma odwzorowywać.

Interpretacja „w duchu” prawa w pierwszej kolejności rozszerza sposób rozumienia celu, przenosząc myślenie z celu danej regulacji na cele systemowe. Wykładnia przepisów prawa ochrony środowiska powinna być w związku z tym prowadzona w kontekście ochrony środowiska jako celu systemowego. Wydaje się często umykać uwadze, że ochrona taka również posiada swoją definicję legalną ${ }^{15}$, jest wartością konstytucyjną ${ }^{16}$, jak też, że ustawa - Prawo ochrony środowiska formułuje zasady ogólne o randze wykraczającej poza ten akt.

Dyrektywami wykładni w odniesieniu do podanych przykładów mogą być w szczególności wynikające ze wspomnianej definicji: racjonalne kształtowanie środowiska i gospodarowanie zasobami środowiska zgodnie z zasadą zrównoważonego rozwoju ${ }^{17}$, jak też - przeciwdziałanie zanieczyszczeniom. Warto dodatkowo zauważyć, że potrzeba postrzegania ochrony środowiska jako systemowego celu została sformułowana także w orzecznictwie Europejskiego Trybunału Sprawiedliwości i to jeszcze przed wprowadzeniem polityki ochrony środowiska do unijnych traktatów (począwszy od sprawy 240/83 ADBHU - wyrok Trybunału z dnia 7 lutego 1985 r. $)^{18}$.

15 Art. 3 pkt 13 ustawy - Prawo ochrony środowiska: „podjęcie lub zaniechanie działań, umożliwiające zachowanie lub przywracanie równowagi przyrodniczej; ochrona ta polega w szczególności na: a) racjonalnym kształtowaniu środowiska i gospodarowaniu zasobami środowiska zgodnie z zasadą zrównoważonego rozwoju, b) przeciwdziałaniu zanieczyszczeniom, c) przywracaniu elementów przyrodniczych do stanu właściwego".

16 Art. 5 Konstytucji RP.

17 Zgodnie z art. 3 pkt 50 ustawy - Prawo ochrony środowiska: „rozwój społeczno-gospodarczy, w którym następuje proces integrowania działań politycznych, gospodarczych i społecznych, z zachowaniem równowagi przyrodniczej oraz trwałości podstawowych procesów przyrodniczych, w celu zagwarantowania możliwości zaspokajania podstawowych potrzeb poszczególnych społeczności lub obywateli zarówno współczesnego pokolenia, jak i przyszłych pokolen'".

18 Wyrok TSUE z dnia 13 września 2005 r. w sprawie C-176/03 Komisja Europejska przeciwko Radzie UE: „41. W tym względzie bezsporne jest, że ochrona środowiska stanowi jeden z podstawowych celów Wspólnoty (zob. wyroki: z dnia 7 lutego 1985 r. w sprawie 240/83 ADBHU, Rec. str. 531, pkt 13, z dnia 20 września 1988 r. w sprawie 302/86 Komisja 
Drugim krokiem ku właściwemu odczytaniu podstawy prawnej decyzji jest identyfikacja i harmonizacja kontekstów, w jakich osadzony jest interpretowany przepis. Zgodnie $\mathrm{z}$ formułowaną przez L. Morawskiego regułą harmonizowania kontekstów (regułą potwierdzania): „[u]stalając znaczenie przepisu $\mathrm{w}$ trudnych i złożonych przypadkach należy brać pod uwagę również kontekst systemowy i funkcjonalny przepisu, a więc na przykład inne przepisy prawne, wolę prawodawcy oraz cel regulacji prawnej"19. Uzasadnieniem stosowania tej reguły jest przede wszystkim dynamika zmian dotyczących prawnego, społecznego i ekonomicznego tła dla rozumienia i stosowania danego przepisu. „[S]ens przepisów prawnych zależeć może nie tylko od kontekstu językowego, ale również od kontekstów systemowego i funkcjonalnego, które w wielu wypadkach ulegają dynamicznym zmianom. W efekcie, przepis, którego sens do pewnego momentu nie budził żadnych wątpliwości może stać się wątpliwy wskutek wprowadzenia nowych przepisów lub radykalnej zmiany sytuacji społecznej czy ekonomicznej, mimo że jego brzmienie nie uległo żadnej zmianie. Bardzo też często zdarza się, iż przepis wzięty w izolacji nie budzi żadnych wątpliwości i dopiero skonfrontowany z innymi przepisami okazuje się wątpliwy"20. Opisane wcześniej stany faktyczne są tego dobitnym przykładem. W tym świetle konteksty dla interpretowanego przepisu jawią się jako zasadnicza determinanta sylogizmu subsumcyjnego.

Budowanie znaczenia interpretowanego przepisu z jego kontekstów i czynienie tychże wagami dla wyniku wykładni, pociąga jednak za sobą pytanie o granice, do których zaakceptować można odejście od wyników wykładni językowej. Problem ten został już dostrzeżony i był wielokroć dyskutowany w orzecznictwie i doktrynie. Sąd Najwyższy podniósł w tym względzie, iż „,[...] zasada pierwszeństwa stosowania wykładni językowej nie oznacza absolutnego porządku preferencji, a jedynie taki porządek, który w uzasadnionych okolicznościach dopuszcza od niej odstępstwa. Przykładem potrzeby odstępstwa jest wskazywana w piśmiennictwie

przeciwko Danii, Rec. str. 4607, pkt 8 oraz z dnia 2 kwietnia 1998 r. w sprawie C-213/96 Outokumpu, Rec. str. I-1777, pkt 32). Podobnie art. 2 WE stanowi, że zadaniem Wspólnoty jest popieranie «wysokiego poziomu ochrony i poprawy jakości środowiska naturalnego», a art. 3 ust. 1 lit. 1) WE przewiduje $\mathrm{w}$ tym celu ustalenie "polityk[i] w dziedzinie środowiska naturalnego»"; zob. też Z. Brodecki, T.T. Koncewicz, Wspólnotowa rozumność, s. 162.

19 L. Morawski, Spory o wykładnie, s. 30, http://www2.wpia.uw.edu.pl/files/doktoranckie/Wyk\%C5\%82ad\%20Prof.\%20Lecha\%20Morawskiego.doc?short= [dostęp: 20.01.2018 r.].

20 Tamże, s. 19. 
sytuacja, w której wynik posłużenia się wykładnią językową prowadzi do absurdów albo do rażąco niesprawiedliwych lub irracjonalnych konsekwencji. [...] W sytuacji natomiast, w której ścisłe, literalne zinterpretowanie przepisu ustawy uniemożliwiałoby sensowne jego zastosowanie bądź prowadziło do zniekształcenia lub wypaczenia jego treści, sięganie przez organ stosujący prawo do innych sposobów wykładni jest jego obowiązkiem. Wykładnia językowa nie może bowiem prowadzić do rozstrzygnięcia, które $\mathrm{w}$ świetle powszechnie akceptowanych wartości musi być uznane za rażąco niesłuszne, niesprawiedliwe, nieracjonalne lub niweczące rationem legis interpretowanego przepisu" ${ }^{21}$. Katalog ten poszerzany jest $\mathrm{w}$ piśmiennictwie o przypadek, gdy sens językowy jest ewidentnie sprzeczny z fundamentalnymi wartościami konstytucyjnymi (a z istotnych powodów uchylenie przepisu byłoby w danym momencie niemożliwe lub niecelowe), jak też o sytuację oczywistego błędu legislacyjnego ${ }^{22}$.

"Granica wykładni, jaką stanowić może językowe znaczenie tekstu, nie jest granicą bezwzględną. Do przekroczenia tej granicy niezbędne jest silne uzasadnienie aksjologiczne, odwołujące się przede wszystkim do wartości konstytucyjnych" ${ }^{23}$. Uprawnienie takie zależy w konsekwencji od „rodzaju normy będącej przedmiotem zainteresowania decydenta w danym momencie procesu, wartości danej subgałęzi prawa administracyjnego czy wreszcie aksjologii całego systemu prawnego" ${ }^{24}$.

Znaczenie przepisu jest więc również pochodną wartości niesionej i chronionej przez prawo, a bezpośrednio w niej nie wyrażonej ${ }^{25}$. W naukowym ujęciu - prawo wartości te presuponuje. Po trzecie zatem, wykładnia przepisów, w tym przepisów prawa ochrony środowiska, powinna dążyć do odczytania wartości założonych w tekście prawnym („,presupozycji

${ }^{21}$ Uchwała SN z dnia 22 marca 2007 r., III CZP 8/07.

22 Zob. L. Morawski, Spory o wykładnie, s. 34.

${ }^{23}$ Wyrok TK z dnia 28 czerwca 2000 r., K 25/99.

24 A. Szot, Swoboda decyzyjna w stosowaniu prawa przez administracje publiczna, Lublin 2016, s. 227.

25 „Nie budzi chyba współcześnie wątpliwości fakt, że między oceną i normą występuje ścisły związek polegający na tym, że każda ustanowiona norma jest «wyrazem» określonej oceny odpowiedniego stanu rzeczy, do którego (przy założeniu efektywności normy) ma doprowadzić. Nie ma więc norm «neutralnych» aksjologicznie", O. Bogucki, Model wykładni funkcjonalnej w derywacyjnej koncepcji wykładni prawa, Szczecin 2016, s. 160, za: M. Zajęcki, Aksjologiczna interpretacja prawa (studium z metodologii i teorii prawa), Warszawa 2017, s. 195. 
aksjologicznych" $)^{26}$. Wartością może być przy tym zarówno dobro obejmowane ochroną przez prawo, na które nakierowany jest cel przepisu, jak i stan tego dobra, którego sposób osiągnięcia albo pożądana charakterystyka, obejmowane są dyspozycją przepisu. W tym ujęciu wartością mogą być, gwoli przykładu: środowisko jako takie, bezpieczeństwo ekologiczne, dziedzictwo naturalne, ale także kształtujące pożądany stan tychże: standard jakości środowiska, dobry stan fizyko-chemiczny i ekologiczny wód, właściwy stan ochrony gatunku lub siedliska przyrodniczego. W niektórych przypadkach (np. przy standardach jakości środowiska), wartość w powyższym znaczeniu powinna być odróżniana od przyjętego przepisami akceptowalnego poziomu ryzyka, opartego nie tyle na ocenie aksjologicznej, co bardziej na modelach statystycznych.

„Wartości są nie tyle stanami rzeczy, co określonymi sposobami uporządkowania stanów rzeczy relacją preferencji. Odpowiednie stany rzeczy są natomiast określonymi stanami dobra (bądź zła) w określonej wartości. Dlatego też można powiedzieć, że określony stan rzeczy nakazany do realizacji w normie sformułowanej celowościowo należy traktować jako dobro w wartości odpowiadającej nazwą temu stanowi rzeczy"27. Na płaszczyźnie naukowej zagadnienie to opisuje i rozwija idea wyważania zasad R. Alexy'ego zaadaptowana na grunt polski przez M. Kordelę. W teorii tej „norma-reguła”, która nakazuje adresatowi realizację pewnego atrybutu-wartości we wskazanej mierze (nakaz all-or-nothing) przeciwstawiana jest „,normie-zasadzie”, która nakazuje adresatowi realizację pewnego atrybutu-wartości w mierze maksymalnie preferowanej na gruncie systemu wartości prawodawcy (nakaz optymalizacyjny all-things-considered). Przedmiotem obowiązku w „normie-zasadzie" jest więc nie tyle sama realizacja normy (weryfikowalna zerojedynkowo), co realizacja wartości. Adresat biorąc pod uwagę okoliczności faktyczne i prawne ma w konsekwencji obowiązek realizować „normę-zasadę” w najwyższym możliwym stop$n^{2}{ }^{28}$. Teoria ta pozwala innymi oczami spojrzeć również na zasady ogólne

${ }^{26}$ W. Wróblewski rozróżnia presupozycje reguł, które odnoszą się do pewnych cech języka prawnego, systemu prawnego i rozumowań prawniczych, presupozycje aksjologiczne oraz presupozycje ontologiczne, dotyczące faktów, za: M. Smolak, Presupozycje ontologiczne tekstu prawnego, "Ruch Prawniczy, Ekonomiczny i Socjologiczny” 2011, z. 4, s. 43-44.

${ }_{27}$ O. Bogucki, Model wykładni funkcjonalnej..., s. 160, za: M. Zajęcki, Aksjologiczna interpretacja prawa, s. 251.

28 Za: M. Zajęcki, tamże, s. 249-262. 
prawa ochrony środowiska, z zasadami prewencji i przezorności na czele. Na ich odniesienie na nowo do opisanych stanów faktycznych - również.

Dla decyzji (stosowania prawa), co wymaga zaznaczenia, dodatkowe znaczenie posiada fakt, iż „,[w]arunkiem niezbędnym zachodzenia presupozycji jest wspólna wiedza nadawcy i odbiorcy komunikatu"29. Decyzja jest więc też wynikiem komunikacji interesariuszy zaangażowanych $\mathrm{w}$ proces wykładni operatywnej $\mathrm{j}^{30}$.

O ile wykładni „litery” prawa przyporządkowywany jest wprost cały system rozumowań prawniczych, o tyle wydaje się, że interpretowanie „w duchu” - także tu: w duchu prawa ochrony środowiska - nie jest wystarczająco definiowane i nie posiada odpowiedniego instrumentarium. Na niedostatki w tej mierze pewną odpowiedzią wydają się być reguła harmonizowania kontekstów oraz presupozycje aksjologiczne przepisów.

Słowa kluczowe: wykładnia prawa ochrony środowiska, reguła harmonizowania kontekstów, presupozycje aksjologiczne

\section{Bibliografia}

Bogucki O., Model wykładni funkcjonalnej w derywacyjnej koncepcji wykładni prawa, Szczecin 2016.

Brodecki Z., T.T. Koncewicz, „Wspólnotowa rozumność” w Trybunale Sprawiedliwości Wspólnot Europejskich, [w:] M. Wyrzykowski (red.), Rozumność rozumowań prawniczych. Materiały z konferencji Zakładu Praw Człowieka Wydziału Prawa i Administracji Uniwersytetu Warszawskiego, która odbyła się 23 stycznia 2008 roku, Warszawa 2008, s. 121-192.

Koncewicz T.T., Jak interpretować prawo europejskie, „Palestra” 2014, nr 5/6, s. 216-222. Leszczyński L., Wykładnia operatywna (podstawowe właściwości), „Państwo i Prawo" 2009, z. 6, s. 11-23.

Morawski L., Spory o wykładnie, http://www2.wpia.uw.edu.pl/files/doktoranckie/ Wyk\%C5\%82ad\%20Prof.\%20Lecha\%20Morawskiego.doc?short= [dostęp: 20.01.2018 r.].

29 M. Smolak, Presupozycje ontologiczne tekstu prawnego, s. 42.

30 Zob. S. Przybyszewski, Kilka uwag o roli kontekstu w komunikacji, „Prace Językoznawcze" 2009, z. 11, s. 179-189. 
Przybyszewski S., Kilka uwag o roli kontekstu w komunikacji, „Prace Językoznawcze" 2009, z. 11, s. 1-9.

Safjan M., Prawa Polska (Seria "Szklane domy"), Warszawa 2005.

Smolak M., Presupozycje ontologiczne tekstu prawnego, „Ruch Prawniczy, Ekonomiczny i Socjologiczny" 2011, z. 4, s. 41-51.

Stelmach J., Efektywne prawo, http://www2.wpia.uw.edu.pl/files/doktoranckie/ STELMACH\%20J.\%20-\%20EFEKTYWNE\%20PRAWO.doc?short= [dostęp: 20.01.2018 r.].

Szot A., Swoboda decyzyjna w stosowaniu prawa przez administracje publiczna, Lublin 2016.

Wróbel A., Sąowa wykładnia prawa państwa członkowskiego UE zgodnie z dyrektywami WE/UE, http://www2.wpia.uw.edu.pl/files/podyplomowe/gospodarka_ rynkowa/wrobel_andrzej.pdf [dostęp: 20.01.2018 r.].

Zajęcki M., Aksjologiczna interpretacja prawa (studium z metodologii $i$ teorii prawa), Warszawa 2017.

\section{THE RULE OF CONTEXTS HARMONISATION AND AXIOLOGICAL PRESUPPOSITIONS IN THE INTERPRETATION OF THE PROVISIONS OF ENVIRONMENTAL PROTECTION LAW}

\section{Sum mary}

Harmonisation of the Polish law of environmental protection and the EU environmental acquis has changed the practice of how the rules are interpreted, directing it into efficiency. However, along with being directed towards the objective of the legislation, the interpretation of the provisions of the environmental protection law, from the EU Treaties to the implementing acts, requires that their spirit, taxonomy and wording be equally taken into account. In the light of the above, the following question arises: what does the interpretation of rules „in the spirit of the environmental protection law" mean? In this regard, three arguments may be put forward: 1) the interpretation of the rules in the spirit of the environmental protection law should be conducted in the context where environmental protection is regarded as the system objective; 2) the proper construction of the grounds for a decision in cases regarding the environment requires that the contexts of the interpreted regulation be identified and harmonised (the corroboration rule); 3) the interpretation of the provision of the environmental protection law should be aimed at identifying the underlying values of the law (,,axiological presuppositions").

Key words: interpretation of environmental law, harmonisation of context, axiological presupposition 


\section{ПРАВИЯО ГАРМОНИЗАЦИИ КОНТЕКСТОВ И АКСИОЛОГИЯ ПРЕДПОЯОЖЕНИЙ В ПРОЦЕССЕ ИНТЕРПРЕТАЦИИ ПОЯОЖЕНИЙ ЗАКОНОДАТЕДЬСТВА О ОХРАНЕ ОКРУЖАЮЩЕЙ СРЕДЫ}

\section{Резюме}

Гармонизация польского законодательства о охране окружающей среды с Евросоюзним environmental acquis изменила практику ведения интерпретации данных положений, направляя ее на эффективность. Около аспекта направленности на цель регулирования, интерпретация положений законодательства о охране окружающей среды, начиная с Трактатов Евросоюза, а, заканчивая, на исполнительных актах, требуется, однако, взять под внимание, их дух, систематику и звучание. На данном фоне возникает вопрос: что значит интерпретация положений „в духе права охраны окружающей среды"? В данном предмете можно поставить три тезиса: 1) Интерпретация положений в духе права охраны окружающей среды должно быть осуществляемым в контексте охраны окружающей среды как системной цели; 2) Соответствующее конструирование основания решения в делах, касающихся среды, требует идентификации и гармонизации контекстов, в которых находится интерпретационное положение (правило подтверждения); 3) Интерпретация положений законодательства о охране окружающей среды, должна стремиться к прочтению ценностей, заложенных в оснований данного права („аксиология предположений”).

Ключевые слова: интерпретация законодательства о охране окружающей среды, правило гармонизации контекстов, аксиология предположений 
